\title{
ON RELATIONS BETWEEN CREATIVITY AND QUALITY MANAGEMENT CULTURE
}

\author{
Enriko CEKO (iD ${ }^{*}$ \\ Department of Economy, Faculty of Economy and Social Sciences, Wisdom University, \\ Street Komuna e Parisit No. 27, PC1010 Tirana, Albania
}

Received 23 February 2020; accepted 4 June 2021

\begin{abstract}
The goal of this study is to make evident the strong connections between creativity and quality management, since creativity and quality management subjects currently are observed with an increasing interest all around the world. The methodology of the research is based on the data collection and information about creativity index and ISO 9001:2015 standards, which are applied in developed, medium income developing countries, as well as in low income developing countries. It has been used a regressive analysis followed by analysis of variance, which resulted on the main conclusion of this study that relations between creativity and ISO standards application is strong. The main recommendation is that application of ISO standards relates mostly to quality and its management, and when it comes to quality of products or services, it refers specifically to the perception of extent to which products and services fulfill customer's expectation and this is related to culture and creativity.
\end{abstract}

Keywords: creativity, culture of quality, culture of quality management, International Organization for Standardization.

\section{Introduction}

When we speak, discuss and argue about creativity, we have to consider it as something new and valuable thoughts, work art, invention, etc.

Currently, there is an increasing interest in creativity and a number of disciplines, mainly related to human and social sciences, such as psycho-sociology, economic-business studies, education, tech-engineering, theo-philosophy, etc., show great interest to the relations between creativity, intelligence, personality, neuro-processes, emotional, psychological, and social well-being, which display a vital potential for improving and exploiting creativity through training and educative programs, aiming economic and social benefit.

Quality's culture as a group of values serve as a guide to continuously improve one's daily activities and results, products and/or services connected to him or her. Quality culture

\footnotetext{
${ }^{\star}$ Corresponding author. E-mail: enrikoceko@yahoo.co.uk
} 
belongs to all members of organization(s) and not only for controllers of quality, organizations where a member is not only customer, but a supplier too, forming a connection of internal clients and suppliers. In every organization the main responsibility is to make sure work quality, focusing on "doing things right at the first time", through management of quality, analyzing poor quality products/services, making corrections during operational processes, making sure the same or similar problem does not occur again. This working culture can be experienced through some values like: (1) development of individuals, (2) active tolerance and respect, (3) entrepreneurship, (4) responsibility, which bring at the end of the day competitive advantage(s).

ISO standards are international standards of quality management, some of which have begun to be demanded currently by private entities all around the world, due to their propensity to achieve competitive advantages in an increasing competitive market. These standards have to do with quality and its management. Quality of products/services refers to perception of extent to which products/services fulfill customer expectations.

Managerial functions are applied and implemented in daily work through a number of modalities and based on these activities public/private entities manage to define policy of quality, strategic and operational aims, responsibilities, and put them in place through planning, control, assurance and improving of quality, applying systems of quality management.

A system of quality management is concerned with quality management, which relates to subject's structure, procedural roles, actions or steps taken in order to achieve a particular end. However, the needed resources to apply management of quality system, includes personnel, occupational safety, environment, human security, production, financials, information, development, procurement, etc.

Organizations operate at national and international level for the application of quality management systems. International Organization for Standardization (IOS), is a federate of standardization bodies in each country. Preparing international standards usually has been handled by committees for technicalities. Works of this organization include international, state and non-state organizations related to IOS. Standards are prepared in compliance with the directives of IOS.

These standards are distributed in every country of the world Boy agencies of standards. Private entities subject to ISO standards are accredited to carry out certification process by accreditation agencies. Public and private entities applying for certification must apply and submitt the relevant documents at these entities which are entitled to carry out ISO certification and are subject to audit process by those entities that issue certificate on basis of confirmation and compliance with standards that the entity requires.

Creativity, quality culture, quality culture management, ISO standards issues are related to corporate social responsibility because sustainable business, business ethics and diversity issues, international and cross-cultural management, national and international (European) organizational culture, culture and sectors of economy in a country, show an important part of history of economic thought (as related to business and management culture). 


\section{Literature review}

Currently, literature for creativity, product/service features, management of quality, systems of managing quality, management of total quality, ISO standards, culture of quality, etc., and other related issues have improved all around the world, besides the country and the level of economic development. This is happening because concepts of quality and ISO standards, if applied correctly, help private and public organisations to be more competitive in a market when the offer is much higher than the demand, which is the main characteristic of last 50 years' world economy.

Over the years of quality management experience, has led us to believe a common idea that innovative products, services, processes, procedures, etc. are part of creativity, or they are somehow related to it (Mumford, 2003; R. J. Sternberg \& K. Sternberg, 2012; Meusburger et al., 2009, pp. 97-154).

The statement above is relvant because creativity serves as a process of thinking how to become aware about problems, lack of knowledge, missing parts, lack of harmonies, etc., and how to identify them, by searching looking for hypothesis to find solutions about problems, testing them and re-testing again, improving and doing modifications, to present final results at the end of process (Torrance, 1966).

Paraphrasing several authors (Amabile \& Pratt, 2016), in this point, we should consider creativity as a separate issue and procedure from innovative procedures that take place inside organizations (OECD, 2018). Saying that, it looks that innovative processes inside organizations are related to implementation of ideas that in a certain sense are creative, while creativity seems to be the creation of new ideas, which should be useful and to be considered.

On the other hand, creativity seems to be related to emotions, as a characteristic of personal abilities for cognitive patterns and this is related to involvement of different creative activities of real life, which mostly are specific (Williams, 2020). Based on this, organizational effective patterns are related heavily to creativity of workforce, while measuring effective and efficiency of organizations, it is in parallel with the vision, mission, strategic and operational objectives, environmental context, nature of work, outputs produced, clients demand and satisfaction (Simonton, 1997). This requires a clear understanding of the structure, values and how the organization(s) works.

In fact, for an organization, to achieve and maintain creativity, managerial practices, motivation and components are needed (Amabile, 1998).

\section{Components are:}

- Knowledge (mental - intellect, technicalities, procedures);

- People with flexibility and imagination to approach issues;

- Intrinsic appeal.

Two types of appeal:

- Extrinsic appeal - external elements, for example threats of being kicked - off or incomes matters;

- Intrinsic appeal - internal elements like work enjoyment, etc.

Practices to encourage appeal:

- Approaching individuals with right challenge;

- Autonomy for people to choose tools to achieve objectives; 
- People, finances, time, etc., as resources kept in balance;

- Supportive working groups with desire to help and support each other;

- Monitoring support - evaluation, mercy, etc.;

- Organization support, cooperation, share of information.

"Knowledge creation and creativity are very important to successful organizations and their results", emphasizing knowledge role on creativity (Siltala, 2010; Sinha et al., 2009). This means that even the idea is wonderful, creativity must follow all the process of innovation from the scratch of the products/service's idea to finalizing it, and in this process, intelligence, innovation and creativity are fundamental for competitive competences of employees (Leal \& Urrea, 2013), because they would encourage people, professionals in their place of work, as an essential factor for innovative approach of organizations, affecting the growth of the economy and positive results of individual businesses. It is evident that, measuring various elements of such processes like encouraging creativity, innovative environment, culture of corporate, optimist approaches, having things under control, etc., helps positively as a whole picture.

Following the idea of connecting knowledge management, creativity, working and organization culture, in a study which regards the impact of organizational culture on creativity, the effect of organizational culture on creativity with an emphasis on the mediating role of knowledge management is really important (Rastgoo, 2017). The results of the research showed a positive and significant effect that the organizational culture has on the creativity of the employees, organizational culture on knowledge management and finally knowledge management on the creativity of the employees (Rastgoo, 2017). Saying that, knowledge and knowledge management are important part of quality management principles. In practice, companies which apply ISO 9001:2015 apply annually training of personnel for new knowledge, as well briefing them in order to strengthen the previous acquired knowledge.

While in another study, authors explain that "organizational culture [...] has an interceding impact on the TQM-SMEs performance relationship", handling a survey to gather information from the small and medium-sized enterprises (SMEs) owners-managers, using a SmartPLS 3.0 in determining the relationship, "showing a positive direct impact of TQM and OC on SMEs' performance, and a critical and positive aberrant impact of TQM on SMEs' performance through OC" (Eniola et al., 2019). The results of this exploration attempt to raise awareness into SMEs' owners-managers in the present unique manufacturing setting, concentrating on total quality management (TQM) as an instrument for improving their performance. The outcomes can help SMEs by giving direction with regard to the organizational culture, on an account of its impact on the effective execution of TQM, in this way improving the dimension of performance. It fills the void in observational examinations on joint impact of TQM and organizational culture on SMEs' performance:

"Psychologists, scientists and managers of organizations have developed in theory integral models that give a positive approach to composition and processes of teams, culture of organizations, reinforcing relationships between them, through promoting innovation" (Woodman et al., 1993).

About relations between creativity and knowledge economy: studies of creative sequences, creating and establishing links with processes of creativity, creation process as a part of subconscious, personality issues on creativity, and creation process inside the organizations 
(Four-C model), might be split in macro-levels, middle-levels and micro-levels, which refers consequently to investigating society or international area, meso-studies organizations, micro-studies on employees (Loo, 2017).

In a study Loo (2017) performed on the issue of how individuals into an organization use their creation mode and knowledge, investigating this issue in three countries (United Kingdom, Japan, Singapore in the sector of information technology and advertising), he has come in a result that learning, qualification and en-cultured workplace is important for a better creative performance, supportive innovations under review of organizations and all of this in intra-sectoral, inter-sectoral and works related to remove some cultures and practices and to adopt some other cultures and practices, which requires an environment of supportive elements like information, communications, technologies infrastructure, training, etc., as necessary conditions for creative work to exist.

This approach implicates informal and formal lifelong learning (3L), finding that education organizations in the near future have to move towards interdisciplinary approach of knowledge, especially on sciences of arts, culture and humanity (Loo, 2017). In a macroapproach, governments have to organize a plenty of cultural, outdoor, and sportive activities, while organizations, have to organize activities to encourage employees in continuous improvement individually and as an organization, establishing and supporting experimental activities.

In another study, which focuses on relations between creativity, organizational culture and quality management, it has been verified that in a hyper-competitive business environment will survive and succeed only those enterprises that are able to come up with a new ideas and/or unique products or applications. Creativity goes hand in hand with innovation; higher creativity leads to more innovation. Developing organizational culture that stimulates and promotes creativity and innovation is an imperative for organizations seeking a competitive advantage (Ali Taha et al., 2016). In this article the strongest association was measured between the atmosphere of psychological safety in the workplace and employees' willingness to produce new ideas and between interpersonal relationships in the workplace and individual creativity. Saying that, quality management tools and standards application brings in place competitive advantage, as well as practical and psychological safety into the organization too.

\section{Composition of team(s)}

Differences between background of group members, improve team creativity by empowering a collection of unique data and culture, approaching different challenges, integrated in new ways, while of course diversity might reduce creativity of working groups, bringing up several difficulties for members of group to exchange and refine ideas, showing in some cases even conflicts between people with different opinions, philosophies, perceptivity and perspective (Harvey, 2013), also the opportunities which are created by potential positive effects of differences between members of the group, should be promoted with clear team creation procedures, in a certain culture of organization, enhancing creative processes (Paletz \& Schunn, 2010). 


\section{Processes of team(s)}

Norms of working group communication, which are: being expert on respecting others, having full attention towards ideas of others, sharing information expectations, disagreement tolerance, negotiation skills, being open to ideas of others, learning from other members of the group, improving creativity of working team by employing and respecting social process(es) used with brainstorming, solving of problems, making group members able to have access on the knowledge and information they have, meet shared vision and understandings, identifying new mode of problems' and task's understanding, brings correlations between ideas and thoughts.

"Being active in processes of social life in organizations, causes a positive affection of the team, which leads to a collective creativity" (Harvey, 2013), while, "positive approach of diversity should be supported by the right processes of working group(s) and culture of organizations, to enhance creative environment" (Paletz \& Schunn, 2010).

\section{Organizational culture}

Regarding the organizational culture, it can be stated that supportive, motivated environment(s) bring safety in psychological side of an organization, by supporting take of risks, tolerance of mistakes, increase creativity between working groups, etc. In organizations where help, support and cooperation are encouraged here is an innovation promotion by offering opportunities to employees in which working group processes works towards group creativity, especially when leadership style motivate employees to discuss about their approaches and this influences on creation of culture of creativity (Harvey, 2013, 2014).

Addressing the issue: "possible positive indications of differences should be motivated by the proper working group procedures and culture of organizations, promoting a creative approach" (Hargadon \& Bechky, 2006).

Some other authors state that there are various individual, organization, and culture factors that influence creativity, or interactions among these influences and processes that foster and suppress creativity. Their discussion focuses on conditions that can bring out the creative potential of employees and how an individual's creativity can be stimulated through forward flow, personal need for structure, proactive personality characteristics, organizational structures that foster an individual's creativity, like a strong support system, transfer of knowledge, and management styles (Hermida et al., 2019).

\section{Restrictions}

The debate on how material restrictions (in terms of financials, resources, or technology) affect creativity, have two competitive sides. On one side, proposal of a negative effect of resources restriction on innovative path, pretending resources restrictions limit the creativity so adequate resources are needed to achieve creativity. On the contrary, the idea which individuals try to find and enforce stable situations, as long as they are not directed on avoidance of resources usage because of restrictions exist. In this issue, "lack of resources is an important 
mover of creative ideas" (Neren, 2011), while, "constrains of materials facilitated the projecting of jet engines in WWII" (Gibbert \& Scranton, 2009), some authors originated their proposal on "contingency models to reconcile these competing views" (Nobre et al., 2010):

"The reason behind the model is that specific factors of contingency (climate of creativity) support relations between creativity and lack of resources, where CF reflects needs for a better level of abilities and promotion, working on duties with creativity under lack of resources and economic situations focused on aspects of creativity impact on economy growth, modeling markets methods for creative solutions, and innovation maximization in an economy" (Weiss et al., 2011).

As per theory of "destruction of creativity" to prescribe the way mode under which old fashion of doing things are avoided and replace by new ones are described by Schumpeter (2008). Some economists have pointed out that:

"[...] creative environment is an effective approach in a new combination of elements to create new technology, new products and new services, positively impacting on economic growth, leading to equity and products of creative nature, protected by patents, marks and brand's laws and rights" (Romer, 2019).

"The creative class is an important driver of economies of modern age": 3T regions (regions that have technology development, talent empowerment and tolerance on differences), because a high concentration of professionals with high creativity characteristics, try to have higher position and impact greately on the development of the economy (Rubenson \& Runco, 1992; Florida, 2014).

Some methods on increasing creativity of an individual have been proposed by researchers, ranging from psychology, cognitive and creative thinking based on science, programs of thinking, tangential thinking, to structured TRIZ (theory of the resolution of inventionrelated tasks) and its variants (Altshuller, 2001; Loh et al., 2006):

"We currently experience a novel time where creative approach is becoming more and more important and in this novel time, we all should support, promote and encourage thinking that represents creativity and emotion, instead of thinking that is focused more on logics and thinking analytically" (Pink, 2006).

Below is listed "an ensemble of techniques of creativity" (Nickerson, 2011):

1. Finding and respecting aim and approach;

2. Forming abilities;

3. Supporting the acquisition of new specific knowledge;

4. Promoting and motivating experimentation;

5. Constructing promotes environment, specifically promotion inside organizations;

6. Promoting risk taking initiatives;

7. Mastering auto-competition;

8. Promoting a supportive values and ideas on creative ideas;

9. Offering chances to choose and explore;

10. Offering conditions for development of auto-management;

11. Learning approaches, helping performance of creativity;

12. Supporting and establishing a balanced environment. 


\section{Managing need for closure}

Several studies suggest that "closure of duties, as prone of personality or caused by pressure of time, impact negatively the creativity" (de Dreu et al., 2008).

Other researchers think that the education system should offer a friendly creative environment, promoting imaginative approach for young generations, since technology enables the advances of nations and economies to a great extend and solving problems in a creative way is required as well as needed to overcome situations in question when they arise: "Creativity is a process that prompts scholars to identify issues and problems in the same point or level where others have failed, and this is more than solving of problems approach" (Kadar et al., 2014).

It is proved that having an intrinsic motivation and problems solutions approach and environment, are main zones where teachers should promote creative activities to students, which are becoming more and more creative if they percept a duty as motivation in an intrinsic way. Promoting thinking in a creative way, teachers should evidence what motivate students and which is the teaching environment around, helping students to choose and complete the right moves to have more intrinsic motivation, which helps them on completing tasks in a creative way (Kadar et al., 2014).

Teaching people how to find solutions for problems without having proper definition of answers is another strategy to improve their creativity, which can be done by allowing students to investigate situations, re-dimensioning them, giving them a chance to draw on information and data which firstly may not seem related to the issue, to find the solution. Mentoring is another way to improve creativity in adults, but this method has been noticed as not to be used in daily creative exposure.

Core definition of quality, as a group of values that helps how improvement is done on daily practice of works and outputs related, as a group of applications taken for granted that forms the philosophy of organizations or working groups, has been identified by several authors, which when paraphrased defines the quality culture as social attack that supports people in organization to stay together (Robbins \& Judge, 2014). “Organization's culture is formed by several variable boxes - interactive modes, values, hypothesis, members, structural mechanisms, control, etc." (Schein, 2010). Culture of quality nature as function of industrial manufactures have been evidended where everyone into organization, not only managers of quality, is in charge for features of products, having as objective the main principle that every employee or team of employees is customer and supplier too, forming a network of insiders clients and suppliers, in charge for each subdivision of the organization to ensure features of the activity they perform, making sure that everything has been done right since first time. Saying that, organizations should make sure they are not part of the process whose results of unsatisfactory products/services are analyzed, because improvements can be done making sure they do not emerge again. In organizations with a strong culture of quality the need to estimate final products/services is required, because they shift responsibility from those taking part at each manufacturing stage (Harvey \& Green, 1993).

Products and services features and improvement of them thrive. This is a culture expressed in several issues: (1) improving individually, (2) tolerance and respect, (3) entrepre- 
neurship (4) having proven capacity: Culture of quality is a group of common, respected and integrally formed approaches of features of products and services, identified on culture of organizations and systems of management (Vlãsceanu et al., 2007).

In Europe, approaches to quality, as well as to culture of quality in universities across Europe, have shifted from principle of "aiming exercises" or "having some value to bring money" (European University Association, 2006), towards the assumption of exploring for excel, establishing, respecting and offering practices which fits the best with standards. In fact, several projects on the issue report that culture of quality has been formed on value, belief and expectation, which are involved as an approach of management that define the responsibilities, objectives, procedures, coordinative support, etc. (Kleijnen et al., 2009).

The importance of quality culture, quality management culture on doing business, achieving competitive advantage, relating them with corporate social responsibility, sustainable business, business ethics, diversity issues, international, cross-cultural management, national/ international organizational culture, culture and sectors of economy in a country, as well as currently as an important part of history of economic thought, related to business management culture (Gordon \& Owen, 2008; Harvey \& Stensaker, 2008; Schein, 2010).

Concepts of quality, quality management, quality management system, TQM, ISO standards, etc., have been classified in several publications (Ceko, 2013, 2017), under the light of last TQM developments, while at several international conference presentations, problems related to quality and quality management in countries have been listed, stressing relations between ISO standards, doing business and life quality (Ceko, 2011, 2016a, 2016b).

Concepts of quality, quality management, quality management systems and TQM have been described in several publications (Kiran, 2017; Ceko, 2017).

Issues of TQM: notions, approach and execution for operations excellence have been described in detail discussing “TQM as a strategy rather than just a technique, providing a comprehensive overview of how TQM helps in attaining operational and business excellence, while it generally covers main basic issues, instruments, methods and functionality linkages of TQM with other operational domains (Sharma, 2018).

In several publications, differences between system's and product's certification have been described (Table 1) (Peri et al., 2004).

ISO standards, their importance, their use in practice, etc. have been described in several publications (Harrington \& Mathers, 1997). Information about standards used in this paper has been taken from ISO publications of final versions of ISO standards listed below.

\section{Concept of quality}

Quality of products/services refers to perception of extent to which products or services offer what customers expect. Features of products/services have no definition unless they relate to one or more specific functions. Quality is something perceptual, conditional and subjective attribute. This is also the reason that in system of ISO standards, and specifically ISO 9000, quality is defined as the degree to which a set of product/service features meet customer requirements. This standard conceives quality as a need or expectation. 
Pointing out: definition of American Society for Quality defines this concept as "a set of product or service features that have capability to meet customer needs", defining that W. Edwards Deming said: "costs must go down and productivity must go up, improving quality through better management of design, testing and improvement of product realization processes and services", paraphrasing Peter Drucker: "quality is not what manufacturers put into a product/service, but what customers receive and are willing to pay" (see Ceko, 2017).

Fully satisfying customer needs and desires: this is substantial and essential in regard to the quality (Ceko, 2017).

System of managing quality:

- Characteristics of total product/service features;

- Management of quality;

- System of managing quality;

- Firm's management".

Characteristics of total features of products and services are (Ceko, 2017):

- Strategy based - total quality is part of vision, mission, objectives;

- Focus on client - client in spotlight;

- Strong link to product or service features - which customer requires;

- Scientific problem solving framework - problem solving tools and techniques;

- Long-term commitment - quality is a journey, not a destination;

- Teamwork - setting quality improvement objectives, processes;

- Continuous improvement process - quality achievement never ends;

- Education and training - of employees to achieve total quality;

- Freedom through control - to express views, perform quality improvement actions;

- Unity of purpose - based on objectives of organization;

- Employee involvement and empowerment - through competencies, quality management.

Managing features of products and services (ISO, 2021; Caswell et al., 1998; Ceko, 2017), managing features of products and services is:

"[...] all actions of managerial functions that define policy of quality, strategic and operational goals, responsibilities and execution through planning, control and assure the of quality and improvement of quality applying systems of quality management" (Ceko, 2017).

And system of quality management -

"[...] culture, procedurals, actions and resources are needed to implement management of quality. In an organization, system of managing quality affects all aspects of business because every system, process, activity and/or task has the potential to generate mistakes and defects" (Ceko, 2017).

Quality management system includes personnel system, occupational safety, environment, human security, production, financials, information, development, procurement, etc. (see Figure 1) (Harrington \& Mathers, 1997). 
Model of a process-based QMS derived from ISO 9001

(roj-20130709)

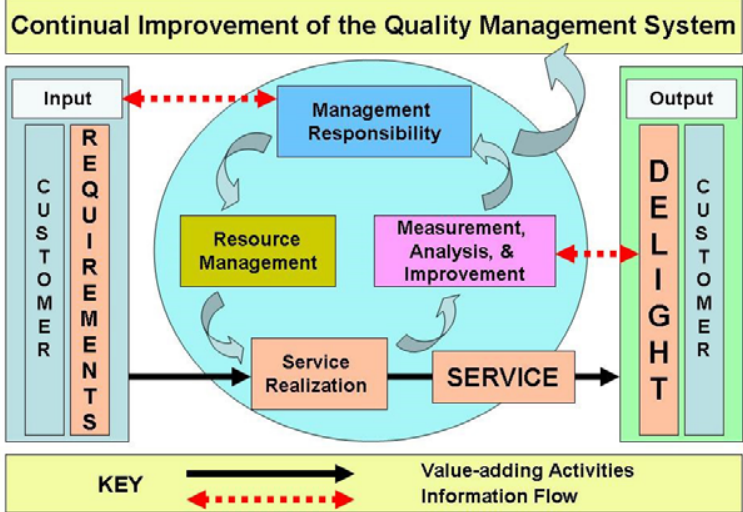

Figure 1. The scheme of relations between management principles and ISO 9000 focus (source: Ceko, 2017)

\section{Identifying system's certification and products and services certification}

On the Table 1 below requirements for certification of quality management systems and requirements for products and services certification have been explained.

Table 1. Differences between quality system's certification and product's certification (source: Ceko, 2017)

\begin{tabular}{|c|l|l|l|}
\hline No. & \multicolumn{1}{|c|}{ Working order } & \multicolumn{1}{c|}{ System's certification } & \multicolumn{1}{c|}{ Product's certification } \\
\hline & Object of certification & Entreprise quality system & Product's characteristics \\
\hline & Norm of reference & Standard & $\begin{array}{l}\text { Technical specifications of } \\
\text { product }\end{array}$ \\
\hline & Certification's body & $\begin{array}{l}\text { Subject that issues relevant } \\
\text { certificate for quality system } \\
\text { sustainable way, constantly, and }\end{array}$ & $\begin{array}{l}\text { Ability of enterprise to produce } \\
\text { in reducts and services in a } \\
\text { thatition mode } \\
\text { constant mode to declared } \\
\text { characteristics }\end{array}$ \\
\hline & Result & Confortificate for quality of product \\
\hline certition certificate & Marc of conformity \\
\hline
\end{tabular}

\section{International standards organization and some of the most required ISO standards for certification}

\subsection{International standards organization}

ISO (2021) is a federate of national entities of standardization. Preparing international standards is carried out by committees of technicalities. These standards are prepared in accordance with rules given by IOS and Directives of International Commission of ElectroTechnique. 
The main duty of these committees is preparing standards. To publish a standard as international requires consent of a minimum $75 \%$ of member bodies participating in process. Standards drive change, facilitate quality assurance, provide assurance, unify test methods and procedures, facilitate communication in general, setting what is a "standard" for products/services, contribute significantly to country's economic growth, are a tool in hands of producers to enforce legislation, encourage increased competition, facilitate trade, eliminate technical barriers to trade and ensure the right level of ecology, sustainability and environmental protection.

\subsection{Some of most required ISO standards for certification}

The following standards are very necessary for public-private entities all around the world, especially in the developing countries.

ISO 9001 - systems managing quality is currently one of the most applied standards. Entities certified in compliance with this standard have more chances/opportunities to achieve competitive advantage in market and in public procurement; it defines what is needed to ensure quality of products/services consistently, in order to achieve a high level of customer satisfaction and for improvement (O'Regan, 2002). This is the main standard required in the world;

ISO 14001 standard - environment protection, which is one of most required standards in world, provides a practical framework for companies that want to manage the existing and potential environmental risks;

ISO 27001 standard - information security management, which is one of most sought standards in world; it increases opportunities for certified entities with this standard to have more opportunities to receive more management and protection information, information on the technologies they own, in face of hackers and competitors these companies have. ISO 27001, information security management, is designed to ensure security of information technology;

ISO 45001standard - occupational health and safety standard. It is one of most sought standard in world. It is a framework for managing in effective way procedures for health and safety at work in all aspects of managing risk and compliance with the law;

ISO 50001 standard - refers to energy management, which is one of most sought after standards in world, increases opportunities for companies to manage better energy and to comply with legislation in force on energy and energy resources management.

The standards ISO 14001, ISO 45001 and ISO 50001, usually are required together with ISO 9001 standard.

Focusing on the issue of relations between culture, creativity and quality management, IOS has issued currently several standards related to corporate culture, business innovation, creativity, etc. as ISO 56001:2019 (innovation management system), as well as new versions of ISO 9001:2015 (quality management system), ISO 14001:2015 (environmental protection management), ISO 22000:2018 (food quality), ISO 45001:2015 (health and safety at work), ISO 50001:2015 (energy efficiency), etc. All of them focused on work conditions, training, risk management, performing internal audits, working culture, etc. 


\section{Methodology}

The literature review revealed major theoretical gaps in relations between creativity and quality management. Specifically, while acknowledging the importance of these two concepts on doing business and entrepreneurship ecosystem, prior empirical researches do not explain how creativity connects to quality management. Thus, a theory is needed, supported by analysis and evidences. An exploratory approach was adopted using a single in-depth case study approach, appropriate on building an in-depth understanding of a phenomenon and allows closer investigation of theoretical constructs.

\subsection{Case selection}

The case was selected based on three main criteria: theoretical approach, suitability of relations, and practical positive impacts on relations between creativity and quality management.

The case project ran in stages: (1) identifying needs for creativity, (2) identifying needs for quality management, (3) identifying the rank of the countries as per issues of creativity, quality management and (4) testing relations.

\subsection{Data collection}

Data for creativity has been gathered from Creativity Index Report.

Data for ISI 9001 standard application has been gathered by ISO Report 2015-2020, while the percentage of ISO 9001 standard application per country has been drawn by comparing the number of ISO 9001 certificated issues per country divided per total number of business entities of the country, later listed in Table 2.

Two following types of data have been used: data from international indexes and websites and data processed by author on ISO standards application per each country.

\subsection{Data analysis}

- The number of each country firms certified with ISO 9001 standards was drawn by ISO website;

- The total number of businesses in countries under the analysis was drawn by different Web pages and other printed and Internet resources like chambers of commerce, house of companies, country annual reports, institutes of statistics, etc.;

- Dividing the number of firms certified with ISO standards with the total number of businesses per country results on percentage of ISO 9001 standard firms ranking;

- Data of countries about creativity was taken from Creativity Index Report;

- A regressive analysis between creativity and ISO 9001 certification ranking data was performed and shown in Figure 2 and in Table 3. 
Table 2. Creativity index and ISO 9001 certificates per country (source: created by author)

\begin{tabular}{|l|c|c|}
\hline \multicolumn{1}{|c|}{ Country } & $\begin{array}{c}\text { Creativity } \\
\text { Index }\end{array}$ & ISO 9001 certificates \% \\
\hline United Kingdom & 0.881 & 0.019 \\
\hline Germany & 0.837 & 0.019 \\
\hline Ireland & 0.845 & 0.016 \\
\hline Netherlands & 0.889 & 0.0155 \\
\hline France & 0.822 & 0.015 \\
\hline Austria & 0.788 & 0.0146 \\
\hline Portugal & 0.71 & 0.0139 \\
\hline Estonia & 0.625 & 0.0123 \\
\hline Slovenia & 0.822 & 0.012 \\
\hline Latvia & 0.563 & 0.013 \\
\hline Croatia & 0.481 & 0.013 \\
\hline Romania & 0.425 & 0.017 \\
\hline Montenegro & 0.516 & 0.007 \\
\hline Turkey & 0.348 & 0.006 \\
\hline Serbia & 0.484 & 0.005 \\
\hline Albania & 0.197 & 0.0008 \\
\hline
\end{tabular}

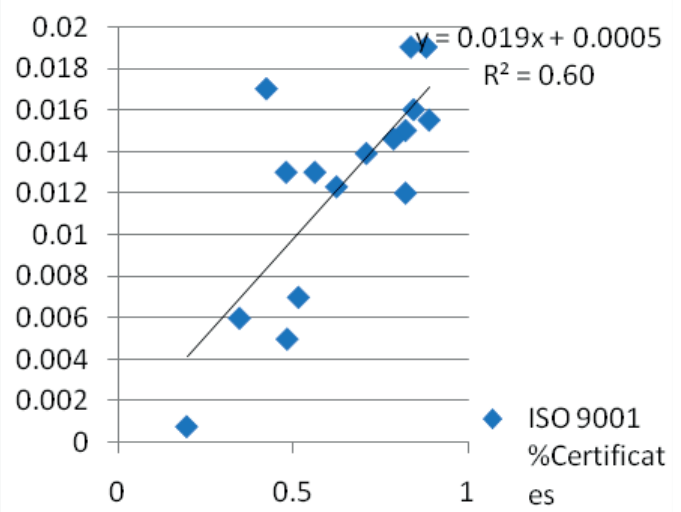

Figure 2. Relations between creativity and ISO 9001 certificates (source: created by author)

\section{Results}

This research produced one main result in relations between creativity and ISO 9001 standards and provided insight into the strong connection which exists between creativity and quality management. 


\section{Summary output}

Table 3. Regression statistics, analysis of variance, relations between a and $b$ and the model (source: created by author)

\begin{tabular}{|l|c|}
\hline \multicolumn{2}{|c|}{ Regression statistics } \\
\hline Multiple R & 0.77 \\
\hline R-square & 0.60 \\
\hline Adjusted R-square & 0.57 \\
\hline Standard error & 0.0034 \\
\hline Observations & 16 \\
\hline
\end{tabular}

\begin{tabular}{|l|c|c|c|c|c|c|}
\hline \multirow{2}{*}{$\begin{array}{c}\text { Analysis of } \\
\text { variance }\end{array}$} & $\begin{array}{c}\text { Degress of } \\
\text { freedom }\end{array}$ & $\begin{array}{c}\text { Quadratic } \\
\text { sums }\end{array}$ & $\begin{array}{c}\text { Quadratic } \\
\text { mean }\end{array}$ & Fisher Test & Significance & $\begin{array}{c}\text { Critic } \\
\text { significance }\end{array}$ \\
\cline { 2 - 7 } & $d f$ & $S S$ & $M S$ & $F$ & Significance F & Fcrit \\
\hline Regression & 1 & 0.0002415 & 0.0002415 & 20.67 & 0.00046 & 4.6 \\
\hline Residual & 14 & 0.0001635 & $1.168 \mathrm{E}-05$ & & & \\
\hline
\end{tabular}

\begin{tabular}{|l|l|c|c|c|c|c|c|c|c|}
\hline & & $\begin{array}{c}\text { Coef- } \\
\text { ficients }\end{array}$ & $\begin{array}{c}\text { Standard } \\
\text { error }\end{array}$ & t-statistic & P-value & $\begin{array}{c}\text { Lower } \\
95 \%\end{array}$ & $\begin{array}{c}\text { Upper } \\
95 \%\end{array}$ & $\begin{array}{c}\text { Lower } \\
95.0 \%\end{array}$ & $\begin{array}{c}\text { Upper } \\
95.0 \%\end{array}$ \\
\hline $\mathrm{a}=$ & Intercept & 0.00050 & 0.00276 & 0.18252 & 0.8578 & -0.00542 & 0.00643 & -0.00542 & 0.00643 \\
\hline $\mathrm{b}=$ & $\begin{array}{l}\text { Creativity } \\
\text { Index }\end{array}$ & 0.01867 & 0.00411 & 4.54668 & 0.0005 & 0.00986 & 0.02747 & 0.00986 & 0.02747 \\
\hline
\end{tabular}

\begin{tabular}{|l|c|c|}
\hline & $\mathrm{y}=\mathrm{a}+\mathrm{bx}$ & \\
\hline Model & $\mathrm{y}=0.019 \mathrm{x}+0.0005$ & $\mathrm{y}=\mathbf{0 . 0 1 9}$ (Creativity Index) $+\mathbf{0 . 0 0 0 5}$ (itercept) \\
\hline & $\mathrm{R}^{2}=0.60$ & \\
\hline
\end{tabular}

The coefficient shows that at ISO $60 \%$ can be explained under the indication of creativity factor.

Relation (connection) between them is strong $(\mathrm{r}=0.77)$.

Using data - data analysis in Microsoft Excel, regressive equation y $=0.019 \mathrm{x}+0.0005$ has been found, while $\mathrm{R}^{2}$ coefficient $=0.60$ and correlation coefficient " $\mathrm{r}$ ".

To analyze if the model of the relations "is god" (which in fact results as such) variance analysis has been used, or " $\mathrm{t}$ " test (Student's Test).

Hypothesis:

$\mathrm{H} 0$ - the model is not good, with the security level $\alpha=0.05$; H1 - the model is good.

Using analysis of variance with the Fisher Test it has been found that $\mathrm{F}_{\text {llog }}>\mathrm{F}_{\text {crit }}$ or Significance $\mathrm{F}$ (probability getting these results) $<\alpha=0.05$ (the security level taken into the account), that shows $\mathrm{H} 0$ is not valuable and $\mathrm{H} 1$ has been verified.

So the model found shows very well the relation between creativity and ISO standards with the security level 0.05 or level of reliability $=95 \%$. 


\section{Context of the research}

Before coming to the results, conclusions and recommendations, it is important to understand that this research showed a representative case of developed, medium income developing countries, as well as low incomes developing countries, which were taken into the consideration randomly, because it was almost impossible to find data about ISO 9001 standards applications for all countries.

It is important to realize that in such situations other important factors influence the behavior of SME's, which are external factors related to politics, general macroeconomic situation, lack of valuable resources, higher costs of production, small market, lack of export - import activity, etc., which have their indications to creativity and quality management and vice versa.

\section{Discussion}

Based on our results, this paper makes a major contribution. It confirms relation between creativity and quality management based on the fact that the observed case context confirms the general view on these relations, as discussed in the literature and describes by the table, graph, and regressive analysis built to confirm the answers for the main question of the research.

\section{Implications for theory and practice}

This study presents a number of theoretical and practical implications. First, it contributes to development of theoretical understanding of relations between creativity and quality management. Second, it extends the theory of management and entrepreneurship. Last but not least, this paper contributes to the creativity and quality management literature in general, seeing these two concepts as very important on entrepreneurship skills, doing business, management, etc.

\section{Limitations and further research}

Besides rigorous data collection and analysis procedures, the research has certain limitations resulting from the choice of methodology and approach. It is a case study, based only on existed data of countries taken into the analysis, but the positive issue is that 17 countries have been taken into the consideration, drawn by incomes, indexes and number of firms certified with ISO 9001 standard.

Because of this, as per the specifics of the observed case, the research can be the framework and can serve as development of any theory of management in that stage of creativity and quality management approach.

Future research could focus on developing and validating the framework through more focused studies, such as data collection and analyzing them for regions and group countries as well as in global level, which would help to determine the current approach and the trends of the future. 
Researchers could also explore the phenomenon of relationship between creativity, quality management and other indexes too.

\section{Conclusions and recommendations}

1. Currently, literature for creativity, product/service features, management of quality, systems managing quality, TQM, ISO standards, culture of quality, etc., has improved all around world;

2. Quality's culture as a group of values serve as a guide on how to improve continuously daily activities and results, products and/or services connected to them. As per this concept, everyone into the organization is responsible for quality;

3. Quality culture, quality culture management and ISO standards issues are related to corporate social responsibility sustainable business, business ethics and diversity issues, international and cross-cultural management, national and international (European) organizational culture, culture and sectors of economy in a country, as well as currently it is an important part of history of economic thought (as related to business and management culture);

4. There is a great link between certification with ISO standards and creativity, because these both concepts offer a common pattern for business management and entrepreneurship;

5. Creation of conditions for business entities to achieve, apply and maintain quality management and creativity, to create continuous competitive advantage, in a global world, remains the main duty of public and private sector in short, medium and long term period;

6. In this paper a new, multi-dimensional framework of creativity and quality management has been introduced, consisting of strong relations between them. This suggests achieving competitive advantage requires positive approach towards these concepts, requiring improvement of creativity and quality management climate, seeing this as a general firm's management perspective, while, in a broader context, this study extends the general understanding of the creativity and quality management relations to be used for a future managerial approach/mechanism in real-world situations, suggesting the future research could focus on developing and validating the proposed framework and investigate the issue in more contexts and settings.

\section{Note}

This article has been written under the light of Cultural Studies in Business Erasmus + Project Programme, KA2 Strategic Partnership in Higher Education.

\section{References}

Ali Taha, V., Sirková, M., \& Ferencová, M. (2016). The impact of organizational culture on creativity and innovation. Polish Journal of Management Studies, 14(1), 7-17.

https://doi.org/10.17512/pjms.2016.14.1.01 
Altshuller, G. (2001). 40 Principles: TRIZ keys to technical innovation. L. Shulyak \& S. Rodman (Eds.). Technical Innovation Center.

Amabile, T. M. (1998). How to kill creativity. Harvard Business Review.

Amabile, T. M., \& Pratt, M. G. (2016). The dynamic componential model of creativity and innovation in organizations: making progress, making meaning. Research in Organizational Behavior, 36, 157-183. https://doi.org/10.1016/j.riob.2016.10.001

Caswell, J. A., Bredahl, M. E., \& Hooker, N. H. (1998). How quality management metasystems are affecting the food industry. Review of Agricultural Economics, 20(2), 547-557.

https://doi.org/10.2307/1350007

Ceko, E. (2016a). On relationship between quality management and life quality (a comparative analysis of Balkans with Western European countries). European Journal of Economics and Management Sciences, 2, 34-40. https://doi.org/10.20534/EJEMS-16-2-34-40

Ceko, E. (2016b). Some issues on relations between quality management/ISO Standards application and doing business climate (a comparative analysis of Balkans with Western European countries). European Scientific Journal, 12(7), 124-130. https://doi.org/10.19044/esj.2016.v12n7p124

Ceko, E. (2013). Quality management tools. Planetar University Press.

Ceko, E. (2017). Total quality management. Wisdom University Press.

Ceko, E. (2011). Total quality management and competitive advantage of Albanian firms. Journal of Institute Alb-Shkenca, 4(3), 423-429.

Dreu, de C. K. W., Baas, M., \& Nijstad, B. A. (2008). Hedonic tone and activation level in the moodcreativity link: toward a dual pathway to creativity model. Journal of Personality and Social Psychology, 94(5), 739-756. https://doi.org/10.1037/0022-3514.94.5.739

European University Association. (2006). Quality culture in European universities: a bottom-up approach. In Report on the Three Rounds of the Quality Culture Project 2002-2006. https://www.eminent-haiti.eu/sites/default/files/2020-07/quality\%20culture\%20in\%20european\%20universities\%20 a\%20bottom-up\%20approach.pdf

Eniola, A. A., Kolade Olorunleke, G., Akintimehin, O. O., Ojeka, J. D., \& Oyetunji, B. (2019). The impact of organizational culture on total quality management in SMEs in Nigeria. Heliyon, 5(8). https://doi.org/10.1016/j.heliyon.2019.e02293

Florida, R. (2014). The rise of creative class, revisited. Basic Books.

Gibbert, M., \& Scranton, Ph. (2009). Constraints as sources of radical innovation? Insights from jet propulsion development. Management and Organizational History, 4(4), 385-399. https://doi.org/10.1177/1744935909341781

Gordon, G., \& Owen, C. (2008). SHEEC Theme on the management of quality: cultures of quality enhancement and quality management systems and structures. http://www.enhancementthemes.ac.uk/ docs/report/the-management-of-quality-cultures-of-quality-enhancement.pdf?sfvrsn=12

Hargadon, A. B., \& Bechky, B. A. (2006). When collections of creatives become creative collectives: a field study of problem solving at work. Organization Science, 17(4), 484-500.

https://doi.org/10.1287/orsc.1060.0200

Harrington, H. J., \& Mathers, D. D. (1997). ISO 9000 and beyond: from compliance to performance improvement. McGraw-Hill.

Harvey, S. (2013). A different perspective: the multiple effects of deep level diversity on group creativity. Journal of Experimental Social Psychology, 49(5), 822-832. https://doi.org/10.1016/j.jesp.2013.04.004

Harvey, S. (2014). Creative synthesis: exploring the process of extraordinary group creativity. Academy of Management Review, 39(3), 324-343. https://doi.org/10.5465/amr.2012.0224 
Harvey, L., \& Green, D. (1993). Defining quality. Assessment and Evaluation in Higher Education, 18(1), 9-34. https://doi.org/10.1080/0260293930180102

Harvey, L., \& Stensaker, B. (2008). Quality culture: understandings, boundaries and linkages. European Journal of Education: Research, Development and Policy, 43(4), 427-442. https://doi.org/10.1111/j.1465-3435.2008.00367.x

Hermida, Y., Clem, W., \& Güss, C. D. (2019). The inseparable three: how organization and culture can foster individual creativity. Frontiers in Psychology, 10. https://doi.org/10.3389/fpsyg.2019.02133

ISO. (2021). ISO. https://www.iso.org/home.html

Kadar, M., Muntean, M., \& Marina, L. (2014). Developing a personalized and adapted curriculum for engineering education through an ambient intelligence environment. In J. P. Davim, Engineering education: curriculum, pedagogy and didactic aspects (pp. 26-65). Series: Chandos Learning and Teaching Series. Chandos Publishing. https://doi.org/10.1533/9781780633589.25

Kiran, D. R. (2017). Total quality management: key concepts and case studies. BS Publications. https://doi.org/10.1016/B978-0-12-811035-5.00001-5

Kleijnen, J., Dolmans, D., Muijtjens, A., Willems, J., \& Hout, van H. (2009). Organisational values in higher education: perceptions and preferences of staff. Quality in Higher Education, 15(3), 233-249. https://doi.org/10.1080/13538320903343123

Leal, S., \& Urrea, J. (2013). Ingenio y pasión. LID Editorial Empresarial.

Loh, H. T., He, C., \& Shen, L. (2006). Automatic classification of patent documents for TRIZ users. World Patent Information, 28(1), 6-13. https://doi.org/10.1016/j.wpi.2005.07.007

Loo, S. (2017). Creative working in knowledge economy. Series: Routledge Advances in Organizational Learning and Knowledge Management. Routledge. https://doi.org/10.4324/9781315453095

Meusburger, P., Funke, J., \& Wunder, E. (Eds.). (2009). Milieus of creativity: an interdisciplinary approach to spatiality of creativity. Series: Knowledge and Space. Vol. 2. Springer Science + Business Media B. V. https://doi.org/10.1007/978-1-4020-9877-2

Mumford, M. D. (2003). Where have we been, where are we going? Taking stock in creativity research. Creativity Research Journal, 15(2-3), 107-120. https://doi.org/10.1207/S15326934CRJ152\&3_01

Neren, U. (2011). The number one key to innovation: scarcity. Harvard Business Review. https://hbr.org/2011/01/the-number-one-key-to-innovati

Nickerson, R. S. (2011). Developing intelligence through instruction. In R. J. Sternberg \& S. B. Kaufman (Eds.), The Cambridge handbook of intelligence (pp. 107-129). Cambridge University Press. https://doi.org/10.1017/CBO9780511977244.007

Nobre, F. S., Tobias, A. M., \& Walker, D. S. (2010). A New contingency view of the organization: managing complexity and uncertainty through cognition. Brazilian Administration Review, 7(4), 379-396. https://doi.org/10.1590/S1807-76922010000400005

O'Regan, G. (2002). A practical approach to software quality. Springer-Verlag New York, Inc. https://doi.org/10.1007/978-0-387-22454-1

OECD, (2018). Oslo Manual 2018: Guidelines for Collecting, Reporting and Using Data on Innovation. Series: The Measurement of Scientific, Technological and Innovation Activities. OECD Publishing/ Eurostat. https://doi.org/10.1787/9789264304604-en

Paletz, S. B. F., \& Schunn, Ch. D. (2010). A social-cognitive framework of multidisciplinary team innovation. Topics in Cognitive Science, 2(1), 73-95. https://doi.org/10.1111/j.1756-8765.2009.01029.x

Peri, C., Lavelli, V., \& Marjani, A. (2004). Qualità nelle aziende e nelle filiere agroalimentari. Gestione e certificazione dei sistemi per la qualità, per la rintracciabilità e per l'igiene. Hoepli.

Pink, D. H. (2006). A whole new mind: why right-brainers will rule future. Riverhead Books.

Rastgoo, P. (2017). The impact of organizational culture on creativity: the mediating role of knowledge 
management (case study: Medical Sciences and Health Services University in Bashehr). International Review of Management and Marketing, 7(4), 83-90.

Robbins, S. P., \& Judge, T. A. (2014). Organizational behavior. Pearson.

Romer, D. (2019). Advanced macroeconomics. Series: The McGraw-Hill Series Economics. McGraw-Hill Education.

Rubenson, D. L., \& Runco, M. A. (1992). The psychoeconomic approach to creativity. New Ideas in Psychology, 10(2), 131-147. https://doi.org/10.1016/0732-118X(92)90021-Q

Schein, E. H. (2010). Organizational culture and leadership. Jossey-Bass Publishers.

Schumpeter, J. A. (2008). Capitalism, socialism and democracy. Harper Perennial/Modern Thought.

Sharma, S. (2018). Total quality management: concepts, strategy and implementation for operational excellence. Sage Publications Pvt.

Siltala, R. (2010). Innovatiivisuus ja yhteistoiminnallinen oppiminen liike-elämässä ja opetuksessa. Sarja: Turun Yliopiston Julkaisuja Annales Universitatis Turkuensis. Tom: 304. Turun Yliopisto.

Simonton, D. K. (1997). Creative productivity: a predictive and explanatory model of career trajectories and landmarks, Psychological Review, 104(1), 66-89. https://doi.org/10.1037/0033-295X.104.1.66

Sinha, N., Kakkar, N. K., \& Gupta, V. (2009). Unleash the power of creativity and innovation. International Journal of Sustainable Strategic Management, 1(4), 417-433. https://doi.org/10.1504/IJSSM.2009.030515

Sternberg, R. J., \& Sternberg, K. (2012). Cognitive psychology. Cengage Learning.

Torrance, E. P. (1966). Torrance tests of creative thinking. verbal tests: Forms A and B. Figural tests: forms $A$ and $B$. Personnel Press.

Vlãsceanu, L., Grünberg, L., \& Pârlea, D. (2007). Quality assurance and accreditation: a glossary of basic terms and definitions. M. Seto \& P. J. Wells (Eds.). UNESCO-CEPES.

Weiss, M., Hoegl, M., \& Gibbert, M. (2011). Making virtue of necessity: the role of team climate for innovation in resource-constrained innovation projects. Journal of Product Innovation Management, 28(s1), 196-207. https://doi.org/10.1111/j.1540-5885.2011.00870.x

Williams, J. (2020). Editorial. Quality in Higher Education, 26(1), 1-2. https://doi.org/10.1080/13538322.2020.1743501

Woodman, R. W., Sawyer, J. E., \& Griffin, R. W. (1993). Toward a theory of organizational creativity. The Academy of Management Review, 18(2), 293-321. https://doi.org/10.5465/amr.1993.3997517 